\title{
Successful factors determining the significant relationship between e-governance system and government operational excellence
}

\author{
Almahdy Alhaj Saleh, Imad Fakhri Taha Alyaseen \\ Kulliyyah of Information and Communication Technology, International Islamic University Malaysia, Malaysia
}

\section{Article Info}

Article history:

Received Apr 2, 2021

Revised Aug 5, 2021

Accepted Oct 23, 2021

\section{Keywords:}

E-governance

Government of Syria

Government-citizen

\begin{abstract}
Every government's major objective is to provide the greatest services in order to establish efficiency and quality of performance. Syria's government has understood how critical it is to go in the direction of information technology. However, there are gaps and poor links across government sectors, which has tainted the image of Syrian e-governance. As a result, one of the main aims of this study is to figure out what factors impact Syrians' acceptance of the egovernment system. A total of 600 questionnaires were delivered to Syrian individuals as part of a survey. The data was analysed using the structural equation model (SEM) using AMOS version 21.0. User intention to utilise an e-government system was shown to be influenced by performance expectations, effort expectations, system flexibility, citizens-centricity, and facilitating conditions. Assurance, responsiveness, reliability, tangibles, and empathy are five fundamental factors that have a major impact on government operation excellence. Behavioural Intention is being utilised as a mediator between the government operation excellence (GOE) initiative and the egovernment platform.
\end{abstract}

This is an open access article under the CC BY-SA license.

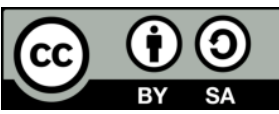

Corresponding Author:

Almahdy Alhaj Saleh

Kulliyyah of Information and Communication Technology

International Islamic University Malaysia

Jalan Gombak, 53100, Selangor, Malaysia

Email: almahdyalhaj@gmail.com

\section{INTRODUCTION}

In recent years, as a result of new technology and conceptions, governance has changed. contact with relation aspect such as organizations and citizens [1]-[3] by launching original service styles, similar to e-learning, e-banking, e-health, e-commerce, e-business, and e-voting are all examples of electronic services, The term "e-governance" was created to describe electronic government. This is a reference to the products and services. supplied by governmental to citizens via providing new information and communication technology technologies that may allow making assistance more quickly and easily. It had been first presented at the $90 \mathrm{~s}$, it is regarded as an innovation introduced by using high-tech development from information technology increase [4].

Most scholars have divided E-governance into three main categories which are: government to government $(\mathrm{G} 2 \mathrm{G})$, government to citizens $(\mathrm{G} 2 \mathrm{C})$, and government to business $(\mathrm{G} 2 \mathrm{~B})$ are three types of G2B. According to Fang and a few other researchers, a fourth category, government to employee, has been developed (G2E) [5]. However, none of the scholars has explored the interaction between the opposite categories beyond the government. Category as they consider them to be the e-commerce a part of the e- 
governance. For instance, business to citizen (B2C), business to employee (B2E) and employee to citizen (E2C), don't seem to be yet identified within the e-governance system [6].

Moving closer to e-governance would provide several benefits to a republic's kind of services, collectively with finances procedure and control. Certainly, it would enhance the processing the national govt in various components in order to improvement of excellence in government operations. A range of these benefits is decreasing expenses and growing activity thanks to the discount of printed paper and acquisition of documents and area for storage [7]-[9].

Reducing the workload on employees is some other advantage to the work environment due to the fact employees are concerned with the minimal quantity of citizens and this can create an increased and serene environment. e-governance will advantage country areas together with large cities since citizens can practice for services lengthy as they're a a portion of republic citizens may be able to participate in some occasions and services. additionally practice for and request a service whilst they're overseas. Further advantages to the environment, knowledge, should even be counted for the improvement of the country [10]. Additionally, e-governance has some challenges and downsides, and these should not be forgotten or ignored. Just to name a few of these difficulties are illustrated underneath cost, unreachability, hypersurveillance, loss of transparency and accountability [11], [12].

\section{LITERATURE REVIEW}

\subsection{E-government}

E-governance, also known as electronic governance, is the combination of information and communication technology (ICT) into the activities with goal of improving government's ability to meet public demands. The primary goal of e-governance is to make procedures easier for everyone, including government, people, companies, and others, at the country, state, and local sectors. It is application for the electronic technology to enhance good governance. It refers to the application of information technology in government processes and activities in order to achieve simple, moral, responsible, and transparent government. It involves the ability to receive government services, information distribution, and timely and effective communication. The strategic objective of e-governance is to achieve this using email addresses, online communities, government discussion websites, and online mediation is to improve information regimes, inform citizens, and engage citizens. As a result, e-duty governance's aims to close the gap between the governed and the rulers by allowing citizens to become more knowledgeable and powerful.

The geographical analysis of linked publications reveals that the e-government website has been researched in a variety of nations, including the United States. Russia, iran, China, Caribbean Island, Indonesia, United Kingdom, South Korea and United Arab Emirates [13]-[23]. Furthermore, a detailed overview of the previous studies reveals that the issue of "e-government" has been examined from a range of viewpoints, with the majority of them focusing on the technological aspects of e-governance, websites, government-to-business [21], and browsing and perusing governmental websites are just a few examples. [13], [14], availability [16], [20], [22], usability [13], [22], quality [23] and from the perspective of users [18], [19]. In a summary, the majority of research recommended creating a perfect e-government system platform that is necessary for residents. It might indicate that most nations require legislative enforcement or other extra methods to promote online accessibility among their companies.

\subsection{Government operation excellence}

The introduction of information communication technologies (ICT) has had a significant influence on the way people' demands are met, as well as government encounters and communication, and its effectiveness is shown in the increasing acceptance of related based on the internet, smartphones, and taps. ICT is still regarded as the essential basis in modern society and digital economy [24]. One of contemporary technology's exhibited potential [25] is its challenge to current power structures and economic connections. This is in addition to the enormous potential for reform and influence on business, people, and government manners and relationships [26], such as offering a critical tool for dissident political organisations throughout the world [27]-[30].

Recently, the attention of scholars and researchers has focused on the government attributes or features which mainly interact with citizens such as websites and support claims. The arguments between different scholars differ from one point to another. Some of them argue that offer access to government information will enhance transparency, while others suggest engaging citizens in official dialogues with the government will increase trust between both parties. Although these different agreements and suggestions consider different points and discussed different targets, their final target is to eliminate the barriers which may impede the government-citizens relationship [26].

Traditional operational techniques for systems will have to be reviewed and re-evaluated [31]. In order to achieve this potential in systems, operational elements must enhance stakeholder management, 
multidisciplinary synthesis, and the successful implementation of operational excellence [32]. Darnell et al. [33] shown in his study that in order to get the most out of any agency's operating excellence, employees should be recognized, and leaders should be given opportunity for further professional growth and a more flexible work environment. This setting, however, cannot be achieved unless the employee has a quiet work space away from the public and hordes of individuals seeking their services.

Darnell et al. [33] furthermore, it was proposed that public services be well advertised in order to gain the target GOE more quickly and efficiently. On the other hand, a single government agency or department cannot achieve full governmental excellence by itself, because offering high-value public eservices in e-government frequently necessitates collaboration between two or more government agencies and departments [34]. Interoperability between intended automated business processes is often used to ensure and achieve such collaboration.

It is, in fact, more logical to question whether governments demand and need to improve and enhance the government's present service shift to a better e-government approach. And so on, nowadays a egovernment is gaining traction is building a number of distinct national administrations are adopting substantial steps in various countries and nations to engage thoroughly in the radical transformation of their portfolios. Generally, one of the popular models in the service quality is [35] five-dimensional SERQUAL model [36]. The SERQUAL model "considered typical methods in the evaluation of the service quality. They put forward that the level of "customer perceived service quality" depends on the difference between the perception of the customer in the service process and the service expectations" [36]. Hence, the assessment of GOE can be based on the same common criterion as is stipulated in the SERVQUAL approach. It can be assurance, tangibles, dependability, responsiveness, and empathy are some of the categories [37].

\section{THE PROPOSED METHOD}

The acceptance of e-governance model by citizens has been a threat in Syria because people do not believe in e-governance. This research shall attempt to study the factors which can enable people to trust and accept e-governance. The present research will use a quantitative approach to research given that it will examine the relationship between several independent variables as well as the e-governance system's acceptance by users in Syria. Citizens-centricity, facilitating conditions, performance expectancy, and effort expectancy are the study's independent variables, whereas government operation excellence (GOE) is the study's dependent variables., flexibility system. And the mediation variable is behavioural intention.

Given the quantitative leanings of the research, the study will thereby focus on existing statistical data, facts and figures. The accompanying data collection tools have been identified as questionnaires. Questionnaires were particularly effective in collecting quantitative data, particularly if researchers are aware of how the variables are to be tested [38]. In addition to this, questionnaires are also effective when it comes to collecting data from a wide sample of respondents, dispersed across a number of locations. Using a questionnaire also allows researchers to ensure that respondents are presented with a uniform set of questions, this will later result in uniform sets of data which are not challenging as far as analysis is concerned. Questionnaires, if designed effectively are unlikely to be time-consuming, therefore enabling for the data collection in such a small amount of time [39], [40]. Given the fact that the research sample is geographically dispersed across Syria, the researcher relied on a questionnaire approach to investigate. Questionnaires, if designed effectively are unlikely to be time-consuming, therefore enabling for the data collection in such a small amount of time [38]-[40]. Given the fact that the research sample is geographically dispersed across Syria, the researcher relied on a questionnaire approach to investigate.

\section{RESEARCH METHOD}

According to [38], The methodology is a set of ideas that must be reduced to a technique that is uniquely appropriate to a given circumstance in any given situation. The research approach for this study offers a systematic and structured technique for examining the link between the many variables involved, namely e-governance, behavioural intention to use, and government operation excellence. In achieving the objectives, the research methodology deals with procedures involved in this research. Questionnaire targeting to survey the adoption information technology for promoting e-governance system among citizens in Republic of Syria are including in the instrument.

Series of tests such as structural equation model (SEM), and reliability analysis were conducted to confirm that the instruments were valid (reliability and convergent validity). Also, The research approach that was used in this study was described in depth. Includes all procedures, processes, and recommendations that are suited for this type of investigation, according to research literature. The primary goal of this study is to look at the role of behavioural acceptability in mediating the link between e-governance and GOE in Syria. 


\subsection{Research framework}

The adoption of information systems, particularly e-governance systems, is impacted by three variables, according to a study of the relevant literature., namely: (1) individual factors (2) system factors (3) environmental factors [41]-[43]. The Implications of DeLone and McLean model, technology acceptance model (TAM), task-technology fit (TTF), and unified theory of acceptance and usage technology are the main theories utilised in this study in terms of theoretical contributions (UTAUT) [44], [45]. We are merging these theories into a new framework in order to attain the best GOE for Syrian citizens in this study.

Hence, the evaluation of GOE will be supported by the equal common criterion as is stipulated within the SERVQUAL approach. It will be classified into assurance, tangibles, reliability, responsiveness and empathy [46], [47]. The goal of this study is to see how e-governance affects the GOE.

H1: An e-governance system and GOE have a significant relationship

\subsubsection{Conceptualization of factors}

An study of information and communication technologies of the literature has shown that Various researches have been performed out to explore at user acceptability of e-governance systems [24]-[26], [48], [49]. The majority of previous studies have focused on employees and citizens environments within economically developed nations. While developing countries have much to gain from utilising information technology, they usually receive little to no attention in regards to research [50]-[52]. To do so, they need to improve upon three aspects: the implementation environment, individual factor, and system factor. In that respect, the current study will aim to in order to improve knowledge of the different aspects that influence Syrian residents' acceptance of the e-government system [53], [54].

\subsubsection{Behavioral intention}

Citizens are encouraged to use a certain software program if it has been utilised or advertised by social organisations, colleagues, or relatives, or any other factor that affects a people's actions or feelings. [55]. This study adding three determinants that are associated of use-intention behaviour of e-governance. They're included to highlight the individual aspect because they have e-governance adoption has a significant influence on people's decisions.

$\mathrm{H} 2$ : The the relation among an e-governance system and government operation excellence is moderated by behavioral intention to use.

\subsubsection{Performance expectancy}

Performance expectancy (PE) is defined by a number of writers, including [56], [57], as an individual's expectations of enhancement while applying a different concept that might increase job performancePerformance expectation appears to be a significant component in determining user intention in ICT environments, according to a slew of studies [58], [59].

Applying this concept (PE) to the e-governance system implies that Syrian citizens believe that using the E-governance system will help them understand more now and, as a result, will enhance their effectiveness. Within an e-governance context, there are many studies which suggest that PE directly influences user intent to use an e-governance system [60]-[62].

H3: Expected performance has a positive impact on behavioural intentions to utilise services provided by the government.

\subsubsection{Effort expectancy}

Both [56], [63] define effort expectation as the amount of comfort users feel when utilising information technology. Effort expectancy has been shown in various research to have a significant impact on behavioural intention. That's also, this same desire to utilize information system technologies [59], [60], and [64]. Throughout this view, effort expectancy theory says that people will typically accept a system if they believe it is uncomplicated to use. This research will aim determine the level to which independent variables such as effort expectations influence the outcome correlate with the aim of implementing an egovernance platform.

H4: Effort expectation will impact behavioural intentions to utilise e-governance services in a positive influence.

\subsubsection{Citizens-centricity (CC)}

The provision of services from the consumer's point of view, rather than the attitude of the government entity, is what a citizen centric approach entails. Antoni et al, Kamaruddin et al [65], [66]. The citizen should be at the centre of every e-governance initiative. Therefore, citizen-centric customer service is a complicated topic with many standpoints that should be examined at the beginning of every new project. Some academics have identified his offering of citizen-centered service as a significant success factor. 
Elsheikh et al. [67] citizen-centered service provision in developing nations, e-governance services determinants would allow for a good knowledge of residents' problems, wants, requirements, and concerns, which governments must consider to guarantee the success of services [68].

H5: Citizens-centricity will have a beneficial impact on behavioural intents to utilise egovernment services.

\subsubsection{System flexibility (SF)}

In the context of e-governance, system flexibility relates to the extent of freedom people think egovernance provides them in terms of time and location. Almahamid et al. [69] system flexibility. This is the capacity to use several procedures and facilities to attain the same objectives. It includes elements like product volume flexibility, persons flexibility, and so on [70].

E-governance literature has also provided us with many studies that indicate the predictive ability of flexibility of e-governance system in determining behavioral intention [46]. In this research, Syrian citizens will adopt the e-governance. People will utilise the e-governance system if they feel they could reach it at any location worldwide.

H6: System flexibility will have a favourable impact on behavioural intents to utilise e-government services.

\subsubsection{Facilitating conditions (FC)}

In 2003, Venkatesh [56] defined Facilitating conditions are the criteria that cause users to feel that Syria's governance infrastructure, both technological and organisational, can operate an e-governance application system. For this regard, enabling, facilitating conditions might lead to the failure of information systems related to a loss of trust in the companies and their systems [57].

Zhang et al. [36] it was also suggested that providing enabling conditions, such as money and time, would drive a person to adopt a specific method. The enabling circumstances construct has a substantial direct impact on user behaviour, according to several research in the information technology area [71]-[73]. Applying this concept to the e-governance system indicates that Syrian residents believe technological infrastructure is important, and governance infrastructure will allowing them to access the e-government system without any problem, and to interact with other users [74].

H7: Facilitating conditions will impcat behavioural intentions to utilise e-governance services in a positive way.

\subsubsection{SERVQUAL}

Parasuraman et al. [75] improved their prior methodology for evaluating service quality. H. Ali [76] The SERVQUAL was established. In brief, the authors argue that a practical service quality assessment develops from a gap in between quality of the service delivered and the client's demands. As a result of completing further research and collecting and analysing new knowledgeThose who are willing to enlarge their impact, lowering the original 10 dimensions to seven; 1) physical items; 2) reliability; 3) responsiveness; 4) communication, credibility, safety, competence; 5) courtesy; 6) customer knowledge; and 7) access.

As showing in Table 1 SERVQUAL was decreased to 5 dimensions reliability, responsiveness, assurance, empathy, and tangibles. Tangibles represent the physical facilities, equipment and appearance of personnel. Reliability refers to the ability to perform the promised service dependably and accurately. Responsiveness is the willingness-to-help users and provide prompt attention. Assurance indicates courteous and knowledgeable employees who convey trust and confidence. The empathy dimension includes offering caring, individualized. These 5 dimensions are used in service quality gap, which implies that there is a difference between the expectations of customers and perception of service at a second step, which involved more research improvement. According to [76], Regardless of the type of service, buyers utilise a similar criterion to evaluate quality. Service quality may be defined as a client's general view of a service's delivery, based on a set of positive or negative experiences. It's tough to live up to the service operations criteria since they require a certain amount of intangibility. In order to address this issue, [77] created a technique that involves a comparison of multiple levels of expectations and patron perceptions of service excellence.

Table 1. SERVQUAL dimensions

\begin{tabular}{|c|c|c|c|c|}
\hline Tangibles & Reliability & Responsiveness & Assurance & Empathy \\
\hline $\begin{array}{l}\text { The physical } \\
\text { appearance of service } \\
\text { delivery devices and } \\
\text { employees. }\end{array}$ & $\begin{array}{l}\text { The capacity to deliver the } \\
\text { given service on time and } \\
\text { on budget, regardless of } \\
\text { any issues that may occur. }\end{array}$ & $\begin{array}{l}\text { The capacity to serve } \\
\text { every client without } \\
\text { hesitation and to promote } \\
\text { the service efficiently and } \\
\text { pleasantly. }\end{array}$ & $\begin{array}{l}\text { When offering a } \\
\text { service, the capacity } \\
\text { to create a sense of } \\
\text { trust, safety, and } \\
\text { technical excellence }\end{array}$ & $\begin{array}{l}\text { The client } \\
\text { unreserved help, } \\
\text { which is focus to } \\
\text { his specific needs } \\
\text { and interests }\end{array}$ \\
\hline
\end{tabular}

As shown in Figure 1, the measurement framework in this study was made up of 42 items to measure 11 constructs, namely: citizens-centricity (CC), facilitating conditions (FC) system flexibility (SF), 
effort expectancy (EE), and performance expectancy (PE) are the e-governnace factors, empathy (EMP), responsiveness (RES), reliability (REL), assurance (ASSU), tangibles (TAN) are the government operion excellance factors with use of the servqual dimenions and behavioral intentions (BI) is the mediation.

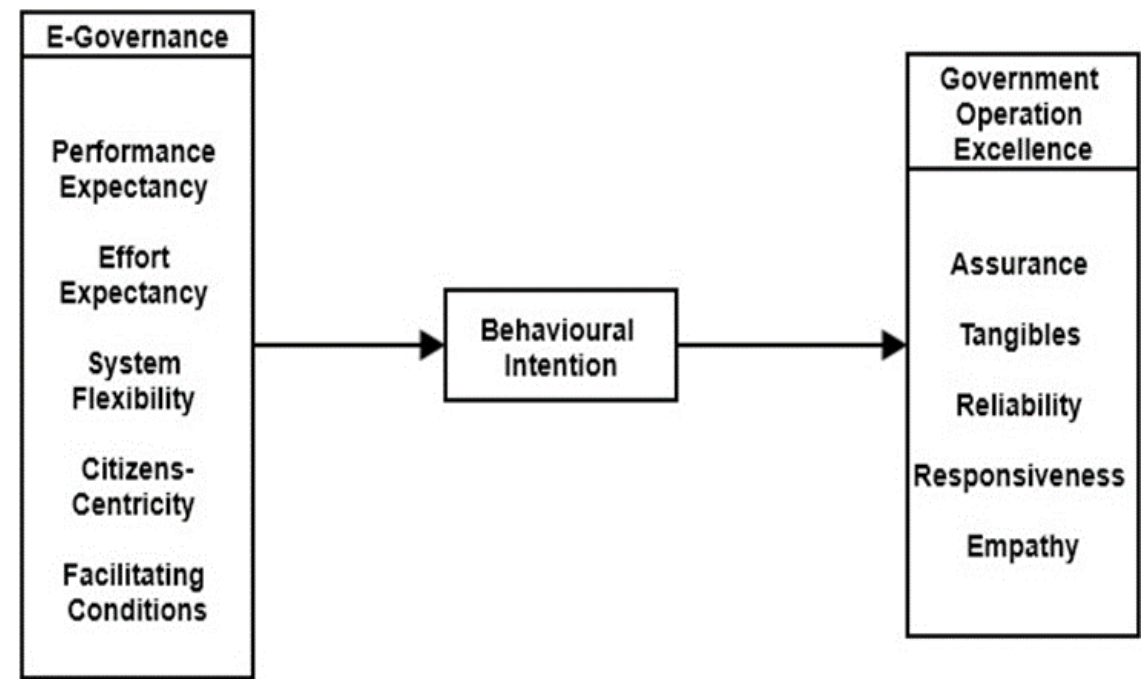

Figure 1. Research framework

\section{DISCUSSION AND RESULTS}

The measurement framework in this study to exmine the convergent validity and relibiity ans also examin the goodness of fit indices.

\subsection{Convergent validity and reliability}

After the completion of the dimensionality constructs, each of the constructs was evaluated for their reliability and validityCronbach's alpha, construct reliability (CR), and average variance extracted (AVE) have been used to measure validity, and constructs such as convergent and discriminant are used to assess reliability.as show in Table 2. Cronbach alpha and convergent validity results for the revised measuring model with 42 reminder items are represented.

As showing in Table 2 that for all constructs, the AVE, which indicates the whole amount of variance in the indicators given for by the latent construct, was greater than the suggested cut-off of 0.5 , ranging from 0.531 to 0.684 . The composite reliability values, which reflect how strongly the construct indicators predict the construct validity, varied from 0.797 to 0.915 , which were all higher than the acceptable value of 0.6 for all constructs as suggested by [78], [79].

Table 2. Cronbach alpha and convergent validity

\begin{tabular}{|c|c|c|c|}
\hline \multirow{2}{*}{ Construct } & \multirow{2}{*}{$\begin{array}{c}\text { Cronbach Alpha Internal } \\
\text { Reliability }\end{array}$} & \multicolumn{2}{|c|}{ Convergent validity } \\
\hline & & Average Variance Extracted (AVE) ${ }^{\mathrm{a}}$ & Composite Reliability (CR) \\
\hline $\mathrm{CC}$ & 0.795 & 0.567 & 0.797 \\
\hline EMP & 0.843 & 0.531 & 0.819 \\
\hline RES & 0.856 & 0.599 & 0.857 \\
\hline $\mathrm{FC}$ & 0.854 & 0.576 & 0.844 \\
\hline REL & 0.896 & 0.684 & 0.896 \\
\hline TAN & 0.858 & 0.632 & 0.872 \\
\hline ASSU & 0.809 & 0.597 & 0.815 \\
\hline BI & 0.862 & 0.557 & 0.863 \\
\hline $\mathrm{SF}$ & 0.862 & 0.611 & 0.863 \\
\hline $\mathrm{EE}$ & 0.914 & 0.641 & 0.915 \\
\hline PE & 0.892 & 0.577 & 0.891 \\
\hline
\end{tabular}

Cronbach's Alpha values, which indicate how error-free a measure is, vary from 0.795 to 0.914 , which are higher than the 0.7 criterion proposed by [80], [81]. As a result, Cronbach's Alpha was proven to be suitably error-free for all constructs. As show in Table 2 the results. The remaining variables have strong factor loadings range between 0.863 to 0.915 , indicating that the variables are still significant. 


\subsection{Goodness of fit indices}

In general, there are Two categories of goodness-of-fit indices, namely a) absolute fit measures such as chi-square statistic, goodness-of-fit statistic (GFI), and root mean square error of approximation (RMSEA), b) Incremental fit measures such as tucker-lewis index (TLI), incremental fit index (IFI), and comparative fit index (CFI).

As show in Table 3 Based on the current GOF results, the chi-square is substantial at the 0.010 level. The normed fit index of lowest difference chi-square can be removed if the sample size for the research is more than 200 [82], [83]. After correcting for degrees of freedom in based on the number of variables, the adjusted GFI, AGFI was 0.867 , which was greater than the recommended cut-off value $>0.80$ according to [84], [85]. The model predicted 86 percent of the variances and covariance in the survey results, according to the report. The model showed a satisfactory fit of collected data on the CFI, TLI, and IFI indices with values more than the cutoff value of $>0.9(0.973,0.973$, and 0.976 , respectively) [86], [87]. In addition, the rootmean-square error of approximation (RMSEA) was 0.020, and that was lower than the suggested threshold of $<0.10$ [88], [90]. Furthermore, the fact that the comparative CMIN/ $\chi^{2}, \chi^{2} / \mathrm{df},(1.224)$ has been less than 5 revealed the good fit of the model [89], [90]. No additional changes are necessary because the new model appropriately matches the data.

Table 3. Modified measurement model GOF indices

\begin{tabular}{cccc}
\hline Fit index & Modified Model & Recommended values & Source \\
\hline CMIN $(\chi 2)$ & 1.224 & & \\
p-value & 0.000 & $>0.05$ & {$[82],[83]$} \\
$\chi 2 /$ df & 1.224 & $\leq 5.00$ & {$[83]$} \\
GFI & 0.881 & $\geq 0.90$ & {$[82]$} \\
AGFI & 0.867 & $\geq 0.80$ & {$[84],[85]$} \\
CFI & 0.973 & $\geq 0.90$ & {$[86],[87]$} \\
TLI & 0.973 & $\geq 0.90$ & {$[86],[87]$} \\
IFI & 0.976 & $\geq 0.90$ & {$[86],[87]$} \\
RMSEA & 0.020 & $\leq 0.10$ & {$[88],[89]$} \\
\hline
\end{tabular}

\section{CONCLUSION}

A average of 600 questionnaires were sent to Syrian individuals as part of the study. From the amount, just 419 questionnaires were received, and only 387 of them could be used (64.1 percent). For each questionnaire, 16 respondents submitted the questionnaire with more than $25 \%$ missing data. Questionnaires with missing data of greater than $23 \%$ should be removed, according to. Additionally, The questionnaire was returned empty by 13 of the respondents. As a result, only 384 instances were utilised in the study's analysis .

Six hypotheses have been explored in order to achieve the research's goals. Five direct relations have been identified out of the total. Users want to take use of the framework of the e-governance system, which is statistically significant, although the research shows also that first performance expectancy and behavioral intention have a strong link (0.000). Effort expectancy and behavioral Intention have a second strong link (0.000). The third stong link is between citizens-centricity and behavioral intention (0.025). System flexibility and behavioral intention have a fourth strong link (0.002)). Facilitating conditions and behavioral intention are the sixth stong link (0.000).

When taking into consideration In order to statistically influence the link between EGOV systems and government operation excellence, two relationships been presented GOE. The coefficient parameter estimations of the structural model are explored and see if EGOV has a positively significant impact on GOE. By Behavioral intention with a total effect of (0.119), the first significant indirect relation between EGOV and GOE was presented. The second significant indirect relation between EGOV and GOE and satisfaction services been presented, with a net impact of (0.097). With Satisfaction Services, a third key indirect link among EGOV and GOE was presented, with an overall effect of (0.185). The fourth important indirect relationship was proposed between EGOV and GOE with a total effect of $(0.118)$. The fifth significant indirect link was postulated between EGOV and GOE and behavioral intention (BI), with a net impact of 0 . (0.087) with BI, a sixth key indirect link between EGOV and GOE were presented, with a net effect of 0. (0.030).

\section{ACKNOWLEDGEMENTS}

I'd like to thank my postdoc supervisor for his help, prof. Dr. Imad Fakhri Taha Alyaseen, the Head, Kulliyyah of Information and Communication Technology, who made this work possible by providing extensive talks and helpful recommendations that substantially improved the article. 


\section{REFERENCES}

[1] M. C. Lee, "Explaining and predicting users' continuance intention toward e-learning: An extension of the expectation-confirmation model," Computers \& Education, vol. 54, no. 2, pp. 506-516, 2010, doi: 10.1016/j.compedu.2009.09.002.

[2] A. Rokhman, "e-Government adoption in developing countries; the case of Indonesia," Journal of Emerging Trends in Computing and Information Sciences, vol. 2, no. 5, pp. 228-236, 2011.

[3] J. R. G. Garcia, J. Zhang and G. P. Cid, "Conceptualizing smartness in government: An integrative and multidimensional view," Government Information Quarterly, vol. 33, no. 3, pp. 524-534, 2016, doi: 10.1016/j.giq.2016.03.002.

[4] A. Grönlund and T. A. Horan, "Introducing e-gov: history, definitions, and issues," Communications of the association for information systems, vol. 15, no. 1, pp. 713-729, 2004, doi: 10.17705/1CAIS.01539.

[5] Z. Y. Fang, "E-Government in Digital Era: Concept, Practice and Development," International Journal of the Computer, the Internet and Management, vol. 10, no. 2, pp. 1-22, 2002.

[6] L. Carter and F. Belanger, "The influence of perceived characteristics of innovating on e-government adoption," Electronic Journal of E-government, vol. 2, no. 1, pp. 11-20, 2004.

[7] I. K. Mensah and S. Adams, "A comparative analysis of the impact of political trust on the adoption of EGovernment services," International Journal of Public Administration, vol. 43, no. 8, pp. 682-696, 2020, doi: 10.1080/01900692.2019.1645687.

[8] O. M. Okunola, J. Rowley and F. Johnson, "The multi-dimensional digital divide: Perspectives from an egovernment portal in Nigeria," Government Information Quarterly, vol. 34, no. 2, pp. 329-339, 2017, doi: 10.1016/j.giq.2017.02.002.

[9] S. K. Sharma, S. M. Govindaluri and R. K. Sharma, "A two-staged regressionneural network model for understanding and predicting the, quality determinants of e-government services in Oman," Proceedings of 4th International Conference on Education and Information Management, 2013, pp. 57-63.

[10] O. Mosud and I. Govender, "Critical issues affecting e-government implementation in Nigeria: a case of housing development agency," African Journal of Gender, Society and Development (formerly Journal of Gender, Information and Development in Africa), vol. 9, no. 4, pp. 33-58, 2020, doi: 10.31920/2634-3622/2020/v9n4a2.

[11] J. C. Bertot, P. T. Jaeger and J. M. Grimes, "Using ICTs to create a culture of transparency: E-government and social media as openness and anti-corruption tools for societies," Government information quarterly, vol. 27, no. 3, pp. 264-271, 2010, doi: 10.1016/j.giq.2010.03.001.

[12] A. I. Alzahrani, "Web-based e-Government services acceptance for G2C: A structural equation modelling approach," De Montfort of Technology, 2011.

[13] M. Vilenskii and O. Smirnova, "Evaluation of web technologies in urban planning management in the largest cities of Russia," GeoJournal, pp. 1-13, 2020.

[14] N. Beygijanian and J. V. Richardson Jr, "E-Government in the Islamic Republic of Iran: reaching out to the world?," IFLA journal, vol. 34, no. 1, pp. 20-33, 2008, doi: 10.1177/0340035208088573.

[15] M. Dokhtesmati, M. Saberi and S. Moradi, "The status of ministries' website of Middle Eastern countries in achieving e-government," World Library and Information Congress: 77 th IFLA General Conference and Assembly, 2011, pp. 13-18.

[16] L. Ma, "Digital governance in China," Handbook of Public Policy and Public Administration in China: Edward Elgar Publishing, 2020.

[17] S. Revinova and D. C. Galvez, "E-government and government support for the digital economy in Latin America and the Caribbean," 2nd International Scientific and Practical Conference "Modern Management Trends and the Digital Economy: from Regional Development to Global Economic Growth"MTDE, 2020, pp. 1003-1011.

[18] A. G. S. Utama, "The implementation of e-government in indonesia," International Journal of Research in Business and Social Science, vol. 9, no. 7, pp. 190-196, 2020, doi: 10.20525/ijrbs.v9i7.929.

[19] N. Nurdin and Z. C. Aratusa, "Benchmarking level interactivity of Indonesia government university websites," TELKOMNIKA Telecommunication Computing Electronics and Control, vol. 18, no. 2, pp. 853-859, 2020, doi: 10.12928/TELKOMNIKA.v18i2.14888.

[20] S. M. Lee, P. Katerattanakul and S. Hong, "Framework for user perception of effective e-tail web sites," Utilizing and Managing Commerce and Services Online: IGI Global, pp. 288-312, 2007, doi: 10.4018/978-1-59140-9328.ch014.

[21] M. A. Awan, "Dubai e-government: An evaluation of G2B websites," Journal of Internet Commerce, vol. 6, no. 3, pp. 115-129, 2008, 10.1300/J179v06n03_06.

[22] T. J. Greitens and J. C. Strachan, "E-government and citizen engagement: An overview of US states' government Websites," International Journal of Public Administration, vol. 34, no. 1-2, pp. 54-58, 2011, doi: 10.1080/01900692.2010.524083.

[23] V. Ratnawati, R. N. Sari, N. M. Zin, S. N. S. Yusuf, J. Haider and A. Ali, “A Panel Data Analysis of the Roles of Education Level and Financial Capacity on E-government Adoption for Higher Transparency and Efficiency in ASEAN Countries," Contemporary Economics, vol. 14, no. 4, pp. 521-531, 2020, doi: 10.5709/ce.1897-9254.423.

[24] H. A. Alwan and A. I. Al-Zubi, "Determinants of internet banking adoption among customers of commercial banks: an empirical study in the Jordanian banking sector," International Journal of Business and Management, vol. 11, no. 3, pp. 95-104, 2016.

[25] W. Beer, "Cybercrime: protecting against the growing threat," Global Economic Crime Survey, retrieved February, vol. 30, pp. 1-40, 2011. 
[26] A. Wiewiora, A. Chang and M. Smidt, "Individual, project and organizational learning flows within a global project-based organization: exploring what, how and who," International Journal of Project Management, vol. 38, no. 4, pp. 201-214, 2020, doi: 10.1016/j.ijproman.2020.03.005.

[27] Hirschfeld, B., "Global Thesis Update: Technology and the Arab Spring," 2012. [Online]. Available: http://worldperspectivesprogram. wordpress. com/2012/04/12/global (Doctoral dissertation, thesisupdatetechnology-and-the-arab-spring)

[28] C. G. Reddick, "Comparative e-government," Springer Science \& Business Media, 2010.

[29] A. M. Al-Khouri, "eGovernment strategies the case of the United Arab Emirates (UAE)," European Journal of ePractice, vol. 17, pp. 126-150, 2012.

[30] L. Bravi, F. Murmura and G. Santos, "Manufacturing labs: Where new digital technologies help improve life quality," International Journal for Quality Research, vol. 12, no. 4, pp. 957-974, 2018, doi: 10.18421/IJQR12.0411.

[31] I. H. Osman and F. Zablith, "Re-evaluating electronic government development index to monitor the transformation toward achieving sustainable development goals," Journal of Business Research, vol. 131, pp. 426440, 2020, doi: 10.1016/j.jbusres.2020.10.027.

[32] L. M. Plà, D. L. Sandars and A. J. Higgins, "A perspective on operational research prospects for agriculture," Journal of the Operational Research Society, vol. 65, no. 7, pp. 1078-1089, 2014.

[33] J. Darnell, S. Cahn, B. Turnock, C. Becker, J. Franzel and D. M. Wagner, "Local health department workforce recruitment and retention: challenges and opportunities," Washington, DC: Center for State and Local Government Excellence, 2013.

[34] A. Elmir, B. Elmir and B. Bounabat, "Towards an assessment-oriented model for external information system quality characterization," IJCSI International Journal of Computer Science Issues, arXiv preprint arXiv:1310.8111, vol. 10, no. 4, pp. 1-8, 2013.

[35] S. Parasuraman and J. A. Alutto, "Sources and outcomes of stress in organizational settings: Toward the development of a structural model," Academy of Management Journal, vol. 27, no. 2, pp. 330-350, 1984, doi: $10.5465 / 255928$.

[36] J. Q. Zhang, G. Craciun and D. Shin, "When does electronic word-of-mouth matter? A study of consumer product reviews," Journal of Business Research, vol. 63, no. 12, pp. 1336-1341, 2010, doi: 10.1016/j.jbusres.2009.12.011.

[37] J. Huai, "Quality Evaluation of E-Government Public Service," International Conference on Management and Service Science, 2011, pp. 1-4, doi: 10.1109/ICMSS.2011.5999011.

[38] [38] U. Sekaran, "Research Methodology for Business (Translation)," Fourth Edition, Jakarta, Salemba Four, 2007.

[39] A. Wozencroft and R. Hardin, "Examining Counselor Satisfaction in an Outdoor Therapeutic Recreation Camp," Entertainment Management, pp. 50-52, 2011.

[40] A. Ahmed and A. S. Almahdy, "Syrian E-Government Framework Toward Government Excellence Servic," Технологии разработки информационных систем ТРИС-2019, 2019, pp. 248-259.

[41] S. Mittal, B. P. Zeigler, A. Tolk and T. Õren, "Theory and practice of M\&S in cyber environments," The profession of modeling and simulation: discipline, ethics, education, vocation, societies and economics, 2017.

[42] A. Algharibi et al., "Adapting the Unified Theory of Acceptance and Use of Technology (UTAUT) as a Tool for Assessing Future Technology Adoption of e-Trial Software Tools," Proceedings of the 10th International Conference on Information Communication Technologies in Health, 2012, pp. 258-267.

[43] K. A. Al Mansoori, J. Sarabdeen and A. L. Tchantchane, "Investigating Emirati citizens' adoption of e-government services in Abu Dhabi using modified UTAUT model," Information Technology \& People, vol. 31, no. 2, pp.455481, 2018, doi: 10.1108/ITP-12-2016-0290.

[44] A. R. Alkhuwaylidee, "Extended Unified Theory Acceptance and Use Technology (UTAUT) for E-Learning," Journal of Computational and Theoretical Nanoscience, vol. 16, no. 3, pp. 845-852, 2019, doi: 10.1166/jetn.2019.7964.

[45] F. O. Bankole, O. O. Bankole and I. Brown, "Influences on cell phone banking adoption in South Africa: An updated perspective," Journal of Internet Banking and Commerce, vol. 22, no. 3, pp. 1-16, 2017.

[46] C. Nanayakkara and D. Whiddett, "A model of user acceptance of e-learning technologies: A case study of a Polytechnic in New Zealand," Information Systems Technology And Its Applications ISTA, pp. 180-189, 2005.

[47] S. A. Kamal, M. Shafiq and P. Kakria, "Investigating acceptance of telemedicine services through an extended technology acceptance model (TAM)," Technology in Society, vol. 60, p. 101212, 2020, doi: 10.1016/j.techsoc.2019.101212.

[48] H. Al-Khatib, H. Lee, C. Suh and V. Weerakkody, "E-government systems success and user acceptance in developing countries: The role of perceived support quality," bura.brunel, pp. 1-40, 2019.

[49] L. P. González, M. T. Matsuo and R. Colomo-Palacios, "Electronic Business and Marketing," International Journal of Human Capital and Information Technology Professionals, vol. 5, no. 2, pp. 62-65, 1990

[50] T. D. Susanto, M. M. Diani and I. Hafidz, "User acceptance of e-government citizen report system (a case study of city113 app)," Procedia Computer Science, vol. 124, pp. 560-568, 2017, doi: 10.1016/j.procs.2017.12.190.

[51] H. Taherdoost, "Development of an adoption model to assess user acceptance of e-service technology: E-Service Technology Acceptance Model," Behaviour \& Information Technology, vol. 37, no. 2, pp. 173-197, 2018, doi: 10.1080/0144929X.2018.1427793.

[52] Q. Hammouri and E. Abu-Shanab, "Exploring factors affecting users' satisfaction toward E-learning systems," International Journal of Information and Communication Technology Education (IJICT), vol. 14, no. 1, pp. 44-57, 2018, doi: 10.4018/IJICTE.2018010104. 
[53] Z. A. Mohammed and G. P. Tejay, "Examining privacy concerns and ecommerce adoption in developing countries: The impact of culture in shaping individuals' perceptions toward technology," Computers \& Security, vol. 67, pp. 254-265, 2017, doi: 10.1016/j.cose.2017.03.001.

[54] S. Khanra and R. P. Joseph, “Adoption of e-Governance,” Transforming Government: People, Process and Policy, 2019.

[55] S.-Y. Hung, C.-M. Chang and S.-R. Kuo, "User acceptance of mobile e-government services: An empirical study," Government Information Quarterly, vol. 30, no. 1, pp. 33-44, 2013, doi: 10.1016/j.giq.2012.07.008.

[56] V. Venkatesh, M. G. Morris, G. B. Davis and F. D. Davis, "User acceptance of information technology: Toward a unified view," MIS quarterly, vol. 27, no. 3, pp.425-478, 2003, doi: 10.2307/30036540.

[57] F. D. Davis, R. P. Bagozzi and P. R. Warshaw, "Extrinsic and intrinsic motivation to use computers in the workplace 1," Journal of applied social psychology, vol. 22, no. 14, pp. 1111-1132, 1992, doi: 10.1111/j.15591816.1992.tb00945.x.

[58] T. Tang, J. Hou, D. L. Fay and C. Annis, "Revisit the drivers and barriers to e-governance in the mobile age: A case study on the adoption of city management mobile apps for smart urban governance," Journal of Urban Affairs, vol. 43, no. 4, pp. 563-585, 2019, doi: 10.1080/07352166.2019.1572455.

[59] P. Lai, "The literature review of technology adoption models and theories for the novelty technology," Journal of Information Systems and Technology Management, vol. 14, no. 1, pp. 21-38, 2017.

[60] V. Venkatesh and F. D. Davis, "A theoretical extension of the technology acceptance model: Four longitudinal field studies," Management science, vol. 46, no. 2, pp. 186-204, 2000, doi: 10.1287/mnsc.46.2.186.11926.

[61] V. N. Nguyen, T. T. Truong, D. T. Ly and N. H. A. Dagamac, "Perceptions of Environmental Science and Management Students on Synchronous Online Teaching of Environmental Policies: Learning Experience from Southeast Asian Cohort," Pedagogical Research, vol. 6, no. 1, pp. 1-11, 2021, doi: 10.29333/pr/9287.

[62] G. Santos, C. S. Marques, E. Justino and L. Mendes, "Understanding social responsibility's influence on service quality and student satisfaction in higher education," Journal of cleaner production, vol. 256, p. 120597, 2020, doi: 10.1016/j.jclepro.2020.120597.

[63] A. Alshehri, M. J. Rutter and S. Smith, "An implementation of the UTAUT model for understanding students' perceptions of learning management systems: A study within tertiary institutions in Saudi Arabia," International Journal of Distance Education Technologies IJDET, vol. 17, no. 3, pp. 1-24, 2019, doi: 10.4018/IJDET.2019070101.

[64] N. M. Satar, M. K. Saifullah, M. M. Masud and F. B. Kari, "Developing smart community based on information and communication technology: an experience of Kemaman smart community, Malaysia," International Journal of Social Economics, vol. 48, no. 3, pp. 349-362, 2021, doi: 10.1108/IJSE-05-2020-0325.

[65] D. Antoni, A. Syaputra and M. Nasir, "A Literature Review of Infrastructure Capabilities in Shared E-Government Concept," International Conference on Electrical Engineering and Computer Science ICECOS, 2019, pp. 117-121, doi: 10.1109/ICECOS47637.2019.8984537.

[66] K. A. Kamaruddin and N. MdNoor, "Citizen-centric Demand Model for Transformational Government Systems," Pacific Asia Conference on Information Systems PACIS, 2017, pp. 1-13.

[67] Y. Elsheikh and M. Azzeh, "What facilitates the delivery of citizen-centric e-government services in developing countries: Model development and validation through structural equation modeling," International Journal of Computer Science \& Information Technology, vol. 6, no. 1, pp. 77-98, 2014, doi: 10.5121/ijcsit.2014.6106.

[68] A. Tarhini, K. Hone, X. Liu and T. Tarhini, "Examining the moderating effect of individual-level cultural values on users' acceptance of E-learning in developing countries: a structural equation modeling of an extended technology acceptance model," Interactive Learning Environments, vol. 25, no. 3, pp. 306-328, 2017, doi: 10.1080/10494820.2015.1122635.

[69] S. M. Almahamid, "E-government system acceptance and organizational agility: theoretical framework and research agendas," International Journal of Information, Business and Management, vol. 5, no. 1, pp. 4-19, 2013.

[70] A. Alhabeeb and J. Rowley, "E-learning critical success factors: Comparing perspectives from academic staff and students," Computers \& Education, vol. 127, pp. 1-12, 2018, doi: 10.1016/j.compedu.2018.08.007.

[71] B. Al Kurdi, M. Alshurideh, S. Salloum, Z. Obeidat and R. Al-dweeri, "An empirical investigation into examination of factors influencing university students' behavior towards elearning acceptance using SEM approach," International Association of Online Engineering. Retrieved August 23, 2021.

[72] R. Estriegana, J.-A. Medina-Merodio and R. Barchino, "Student acceptance of virtual laboratory and practical work: An extension of the technology acceptance model," Computers \& Education, vol. 135, pp. 1-14, 2019, doi: 10.1016/j.compedu.2019.02.010.

[73] F. Huang, J. C. S. Prieto, T. Teo, F. J. G. Peñalvo, S. O. Migueláñez and C. Zhao, "A cross-cultural study on the influence of cultural values and teacher beliefs on university teachers' information and communications technology acceptance," Educational Technology Research and Development, vol. pp. 1271-1297, 2021.

[74] M. Haming, I. Murdifin, A. Z. Syaiful and A. H. P. K. Putra, "The application of SERVQUAL distribution in measuring customer satisfaction of retails company," The Journal of Distribution Science, vol. 17, no. 2, pp. 25-34, 2019, doi: 10.15722/jds.17.2.201902.25.

[75] A. Parasuraman, V. A. Zeithaml and L. L. Berry, "A conceptual model of service quality and its implications for future research," Journal of marketing, vol. 49, no. 4, pp. 41-50, 1985, doi: 10.1177/002224298504900403.

[76] H. Ali, "Measurement of e-services quality: an empirical study of University of Bahrain," Education and Information Technologies, vol. 24, no. 3, pp. 1907-1924, 2019.

[77] J. C. Nunnally and Ira. H. Bernstein, "Psychometric theory,” New York : McGraw-Hill, (1)1994. 
[78] R. P. Bagozzi and Y. Yi, "On the evaluation of structural equation models," Journal of the academy of marketing science, vol. 16, no. 1, pp. 74-94, 1988.

[79] R. H. Hoyle, "The structural equation modeling approach: Basic concepts and fundamental issues," Structural equation modeling: Concepts, issues, and applications, pp. 1-15, 1995.

[80] P. Y. Chau and P. J. H. Hu, "Information technology acceptance by individual professionals: A model comparison approach,” Decision sciences, vol. 32, no. 4, pp. 699-719, 2001, doi: 10.1111/j.1540-5915.2001.tb00978.x.

[81] B. M. Byrne, "Structural equation modeling with Mplus: Basic concepts, applications, and programming. routledge," New York, Routledge, pp. 1-432, 2013, doi: 10.4324/9780203807644.

[82] J. F. Hair, W. C. Black, B. J. Babin, R. E. Anderson and R. L. Tatham, "Multivariate data analysis 6th Edition," New Jersey: Prentice Hall, 2006.

[83] R. Ho, "Handbook of univariate and multivariate data analysis and interpretation with SPSS," CRC press, 2006.

[84] R. E. Schumacker and R. G. Lomax, "A Beginner's Guide to," Structural Equation Modeling 3rd Edition, New York: Taylor \& Francis Group, 2010.

[85] A. A. Saleh, A. R. Alkhuwaylidee and M. Thangiah, "E-Government System Framework Successful Factors," 2021. [Online].

Availabe: https://www.researchgate.net/publication/348917398_EGOVERNMENT_SYSTEM_FRAMEWORK_SUCCESSF UL_FACTORS/stats

[86] N. R. Mohan, A. Majeed, A. A. Saleh and A. R. Mohain, "Using Cloud-Based Web Application For Universityes: A Case Of University Of Technology In Iraq," Advances In Computing, vol. 4, no. 1, pp. 15-17, 2014, doi: 10.5923/j.ac.20140401.04.

[87] A. Alkhuwaylidee and A. S. Almahdy, "Syrian E-Government Framework Toward Government Excellence Servic," Технологии Разработки Информаџионных Систем Трис-2019, pp. 248-259, 2019.

[88] A. Razzaq, S. A. Asmai, M. S. Talib, N. Ibrahim and A. A. Mohammed, "Cloud Erp In Malaysia: Benefits, Challenges and Opportunities," International Journal of Advanced Trends in Computer Science and Engineering, vol. 9, no. 5, pp. 7510-7516, 2020, doi: 10.30534/ijatcse/2020/85952020.

[89] A. A Saleh, A. R Alkhuwaylidee and M Thangiah, "Successful Factors Determining the user behaviour in information system," Journal of Physics: Conference Series, no. 012161, pp. 1-13, 1963, doi: 10.1088/17426596/1963/1/012161.

[90] A. A. Saleh, A. R. Alkhuwaylidee, M. Thangiah, "Behavioural Intention and User Satisfaction Successful Factors Determining to Achieve Government Operation Excellence" Annals of the Romanian Society for Cell Biology, vol. 25, no. 4, pp. 19977-19989, 2021.

\section{BIOGRAPHIES OF AUTHORS}
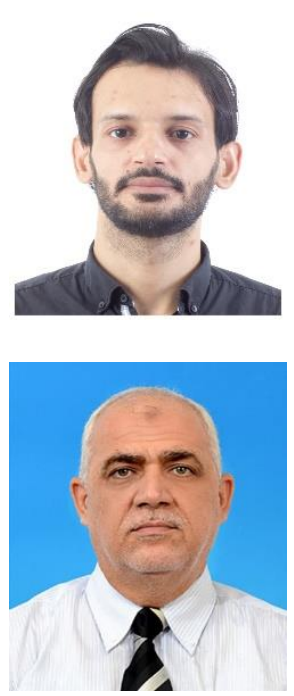

Almahdy Alhaj Saleh a Ph.D degree from limkokwing university, Malaysia 2020, MSc in computer networking 2014 and currently post doctorate fellow at IIUM Kulliyyah Of Information And Communication Technology.

Imad Fakhri Taha Alyassen (prof.dr.) a IEEE senior member, obtained his BSc (Hon) in Mathematics, MSc in Computer Science from Iraq, and Ph. D degree from Pune University, India, 2000. 